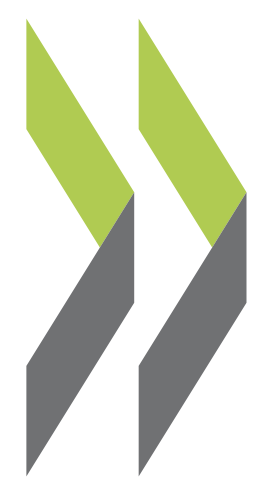

OECD Economics Department Working Papers No. 840 Policies Towards a Sustainable Use of Water Andrés Fuentes in Spain 
Organisation de Coopération et de Développement Économiques

Organisation for Economic Co-operation and Development

02-Feb-2011

ECONOMICS DEPARTMENT

English - Or. English

POLICIES TOWARDS A SUSTAINABLE USE OF WATER IN SPAIN

ECONOMICS DEPARTMENT WORKING PAPER No. 840

By Andrés Fuentes

All Economics Department Working Papers are available through the OECD internet website at www.oecd.org/eco/workingpapers

JT03295841

Document complet disponible sur OLIS dans son format d'origine

Complete document available on OLIS in its original format 


\section{ABSTRACT/RÉSUMÉ \\ Policies towards a sustainable use of water in Spain}

Spain uses its natural water resources intensively, mostly in agriculture, thanks to a highly developed dam infrastructure. The limits for extraction of natural resources have largely been reached and climate change is expected to continue lowering natural water endowments markedly in future especially in dry areas of the country. The costs of exploiting alternative supply sources on a large scale, notably desalination and recycling, remain well above water prices paid by consumers at present. The government has recognised that water policies therefore need to switch to demand management, so as to ensure that available resources are put to most efficient and priority use. Scope for water savings is substantial, especially in agriculture, where much irrigation water generates little value-added. The government has subsidised the use of more efficient irrigation technology at considerable budgetary cost, which has contributed to a modest reduction of water use in irrigation in recent years. The participatory approach in water policy governance should be extended further to stakeholders beyond the irrigation community, to include more scientists or representatives of institutions protecting local ecosystems Low water prices, combined with the free allocation of water concessions, still hamper an efficient use of water resources. Water prices will need to rise further so as to reflect service provision costs in full as well as the scarcity and environmental costs of water abstractions. Steps to better take into account water scarcity should include the progressive inclusion of market instruments, such as the tendering of water concessions as well as the elimination of some barriers to the exchange of such concessions among users. Benchmark regulation of water utilities would contribute to more efficient water supply and treatment services. Further steps need to be taken to halt excessive groundwater abstractions, including through improved monitoring and the introduction of charges on abstractions from overexploited aquifers.

JEL codes: Q25, Q15, Q18.

Keywords: Spain, water resources, groundwater, water scarcity, water use, overexploitation, water policy, water prices, irrigation, river basin authorities, water governance, regulation of water utilities, groundwater management.

$$
* * * * * * * * *
$$

\section{Action en faveur d'une utilisation durable de l'eau en Espagne}

L'Espagne fait un usage intensif de ses ressources naturelles en eau, surtout en agriculture, grâce aux très nombreux barrages qu'elle a mis en place. L'extraction de ces ressources a dans une large mesure atteint ses limites, d'autant qu'elles devraient continuer de diminuer sensiblement à l'avenir sous l'effet du changement climatique, notamment dans les régions sèches du pays. Les coûts d'exploitation à grande échelle d'autres formes d'approvisionnement en eau, comme le dessalement et le recyclage de l'eau, restent bien supérieurs aux tarifs payés aujourd'hui par les consommateurs. Dans ces conditions, le gouvernement a admis la nécessité de recentrer la politique de l'eau sur la gestion de la demande, pour faire en sorte que les ressources disponibles soient affectées aux usages les plus efficients et prioritaires. Il existe d'importants gisements d'économies d'eau, en particulier dans l'agriculture où le rendement de l'eau d'irrigation est souvent faible. Le gouvernement a subventionné l'adoption de techniques d'irrigation plus efficientes, pour un coût budgétaire considérable, ce qui a contribué à une légère réduction de la consommation d'eau d'irrigation ces dernières années. L'approche participative dans la gouvernance de la politique d'eau devrait être étendue à un plus large éventail d'intervenants au delà du secteur de l'irrigation, dont les chercheurs et les représentants d'institutions qui protègent les écosystèmes locaux. Le bas niveau des prix de l'eau, conjugué à l'attribution gratuite des concessions, fait encore obstacle à une utilisation efficiente des ressources en eau. Les prix de l'eau devront encore augmenter afin de refléter pleinement les coûts de fourniture du service, ainsi que le coût de rareté et les coûts environnementaux des prélèvements d'eau. Pour une meilleure prise en compte de la rareté de l'eau, il conviendrait entre autres d'adopter progressivement des instruments économiques tels que la mise aux enchères des concessions et d'éliminer certains obstacles aux échanges de concessions entre les usagers. Une régulation par comparaison des compagnies des eaux contribuerait à accroître l'efficience des services de distribution d'eau et de traitement des eaux. De nouvelles mesures s'imposent pour mettre fin aux prélèvements souterrains excessifs, à commencer par une meilleure surveillance et l'instauration de redevances sur les prélèvements d'eau dans les aquifères surexploités.

Classification JEL : Q25, Q15, Q18

Mots-clés : Espagne, ressources en eau, eaux souterraines, rareté d'eau, usage de l'eau, surexploitation, politiques de l'eau, prix de l'eau, organismes de bassin, gouvernance de la politique de l'eau, réglementations des services de l'eau, gestion des ressources en eau souterraines.

Copyright $($ ) OECD, 2011. All rights reserved. Application for permission to reproduce or translate all, or part of, this material should be made to: Head of Publications Service, OECD, 2 rue André-Pascal, 75775 PARIS CEDEX 16, France. 


\section{TABLE OF CONTENTS}

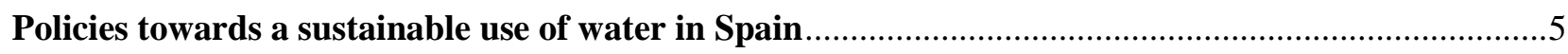

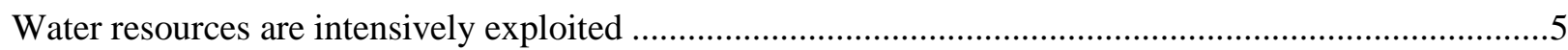

The expansion of water supply through the construction of dams has come to an end ...........................6

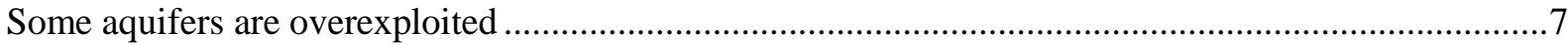

Climate change will further lower the natural supply of water .............................................................9

Low water prices hold back the development of unconventional supply sources..................................

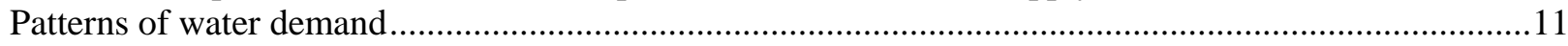

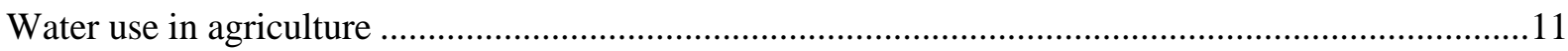

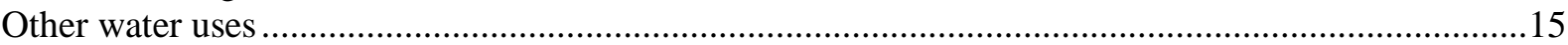

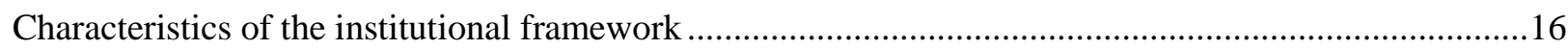

Pricing of water services has important allocative and funding roles .............................................. 18

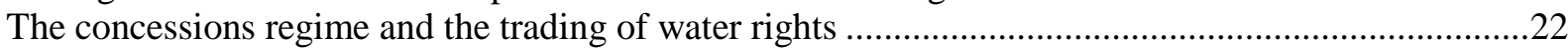

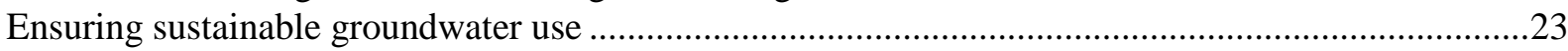

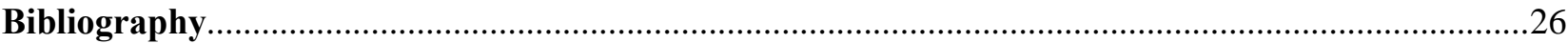

\section{Boxes}

1. The revised National Hydrological Plan (2005-2008): Plan AGUA ...................................................10

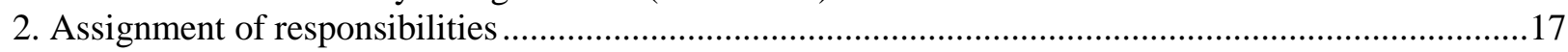

\section{Tables}

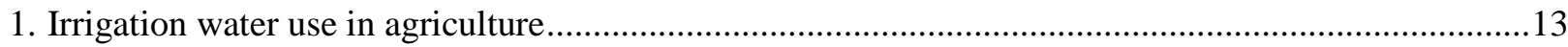

2. Water consumption in irrigation by river basin and profitability range ............................................15

\section{Figures}

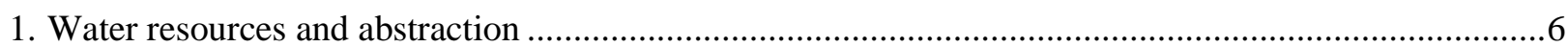

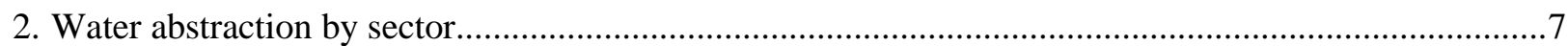

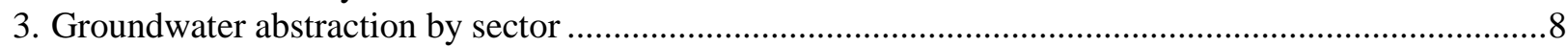

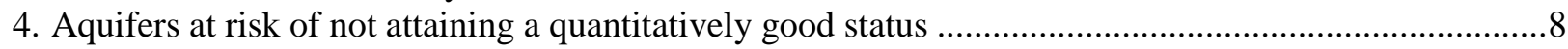

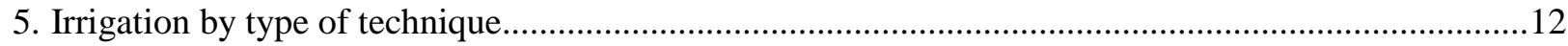

6. Productivity, water use and value added of irrigated agriculture .....................................................14

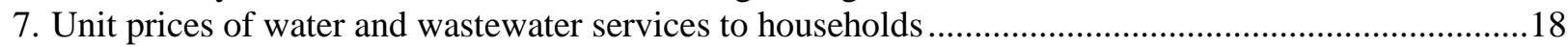


ECO/WKP(2011)9 
ECO/WKP(2011)9

\title{
POLICIES TOWARDS A SUSTAINABLE USE OF WATER IN SPAIN
}

\author{
By Andrés Fuentes ${ }^{1}$
}

\section{Water resources are intensively exploited}

Seventy per cent of Spain's surface is subject to a semi-arid climate with recurring droughts and strong seasonal variability of rainfall. Its climate and the physical characteristics of its environment, such as the prominence of mountain ranges close to the coasts or soil characteristics, make natural water endowments highly unequally distributed across space and time. These characteristics have determined water policies, which used to aim at increasing supply by constructing large dams with government support. With over 1300 dams, Spain is estimated to be the country with the 4th largest number of dams in the world (after the United States, India and China; Martínez-Cortina, 2010). Over the past century this policy increased water abstractions per inhabitant to a higher level, on average, relative to renewable resources, than in most other OECD countries (Figure 1), relatively low population density notwithstanding. The OECD (2004) has therefore assessed water resources to be under moderate stress.

In economic terms the driving force behind the expansion of water storage has been that irrigation allows, on average, to multiply income generated by cultivated land by six (Maestu and Gómez, 2010), especially along the Mediterranean coast, where part of agricultural activity is strongly export-oriented, reflecting a number of factors that have given irrigated agriculture a comparative advantage such as long sunshine, the ample availability of soil and the proximity of markets. However, in recent decades the weight of agriculture has much diminished, with the share in economic activity dropping to $2 \frac{1}{2}$ per cent, a share similar to that observed in other high-income countries. The value added of related manufacturing amounts to an additional $2 \%$ of GDP. In some regions, agriculture remains an important economic factor, especially in the south east, which is also where some of the river basins most affected by water scarcity are located (see further below).

1. Senior economist in the Economics Department. This paper was originally prepared for the $O E C D$ Economic Survvey of Spain published in December 2010 under the authority of the Economic and Development Review Committee (EDRC). The paper has much benefited from suggestions from Josefina Maestu and Roberto Martín-Hurtado as well as from Desney Erb's research assistance. The author would also like to thank Kevin Parris, Aziza Akhmouch, Andrew Dean, Robert Ford, Pierre Beynet and Juan S. Mora-Sanguinetti for comments on earlier drafts. The paper has also benefited from discussions with Francisco Cubillo, Lorenzo Galbiati, Gonzalo Saenz de Miera and Antonio Serrano Domínguez. Special thanks go to Desney Erb and Maartje Michelson for editorial assistance. 
Figure 1. Water resources and abstraction
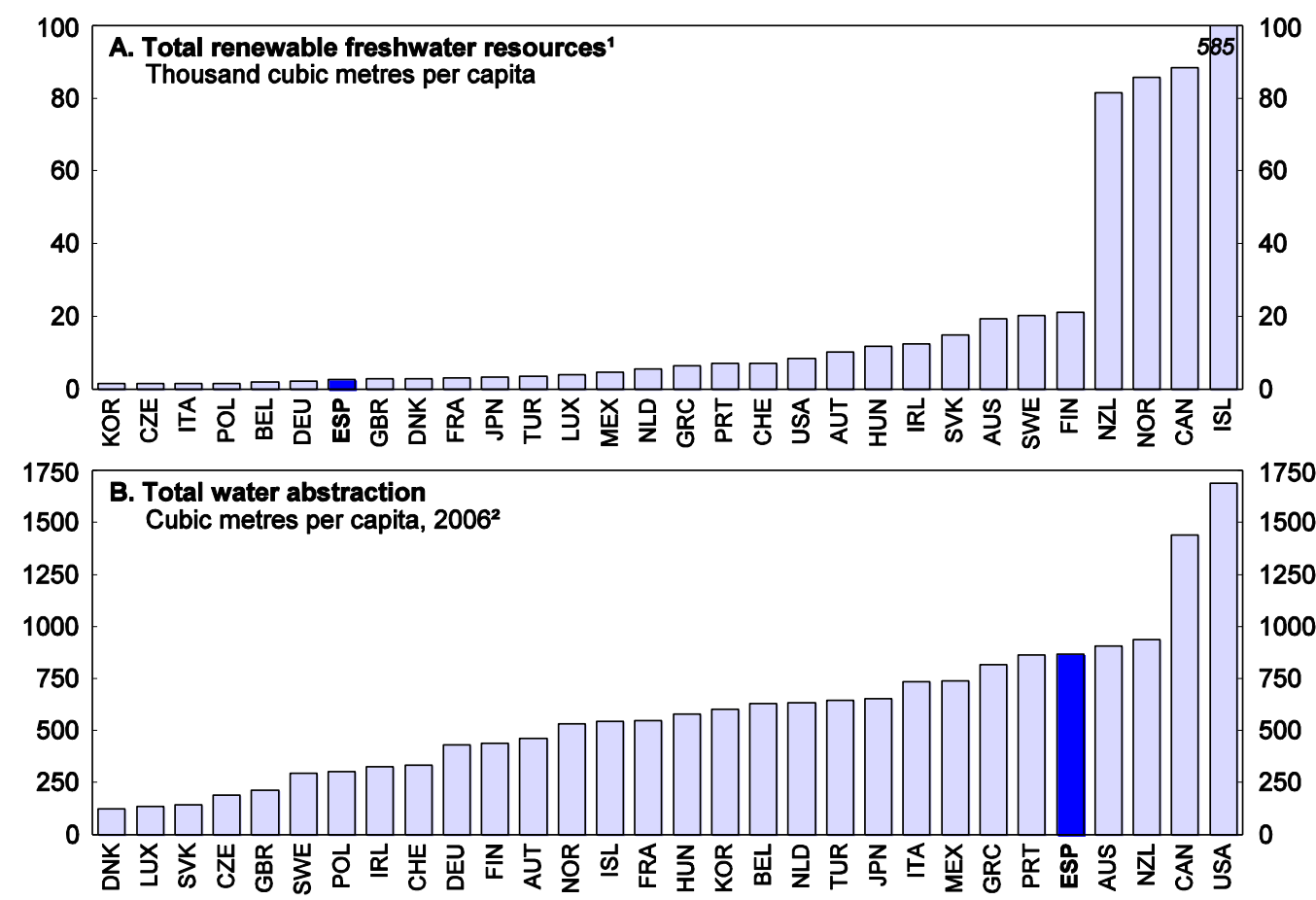

1. Estimates of long-term annual averages of renewable freshwater resources which aggregate the quantity of water received from precipitation (net of evapotranspiration) and from inflowing rivers from neighbouring countries.

2. 2000 for Italy, Luxembourg, Portugal and United States; 1995 for Canada, Greece and Ireland.

Source: OECD (2010), OECD Environmental Data Compendium 2006-08 and OECD Economic Outlook: Statistics and Projections (database), April.

\section{The expansion of water supply through the construction of dams has come to an end}

Spain is one of the few high-income OECD countries where water abstractions continued to increase through the 1990s (OECD, 2010a), although they have levelled off in recent years (Figure 2). The decline in 2005 and 2006 can to some extent be attributed to a marked decline in precipitation, which reduced water supply to irrigated agriculture, reflecting the priority water legislation assigns to urban water consumption (see below). A consensus has emerged that the scope for expanding water supply through new large-scale hydraulic projects has ended. (See e.g. Arrojo Agudo, 2010, and the other authors in Garrido and Llamas, 2010. Moreover, according to a survey in Terceño-Gómez et al., 2009, local water experts in all water basins did generally not consider extending surface water storage capacity or raising groundwater extraction as the most desirable options for coping with water scarcity). This is in part due to the environmental impact a further increase in surface water abstractions would have, for example on river flows and dependent natural habitats. River flows have fallen substantially over past decades: for example the Ebro lost almost half of its average run-off between 1947 and 1997 and this decline may have accelerated markedly from the late 1960s. This development reflects the expansion of irrigation, reforestation and climatic change, with each of the three estimated to account for a similar share of the decline (see Barcelò, 2008 where Gallart and Llorens, 2004 are cited). Surface water quality has improved markedly in past decades, with most river flows assessed to have attained at least satisfactory standards (MARM, 2008a). 
Figure 2. Water abstraction by sector

Total surface and groundwater, billion cubic metres

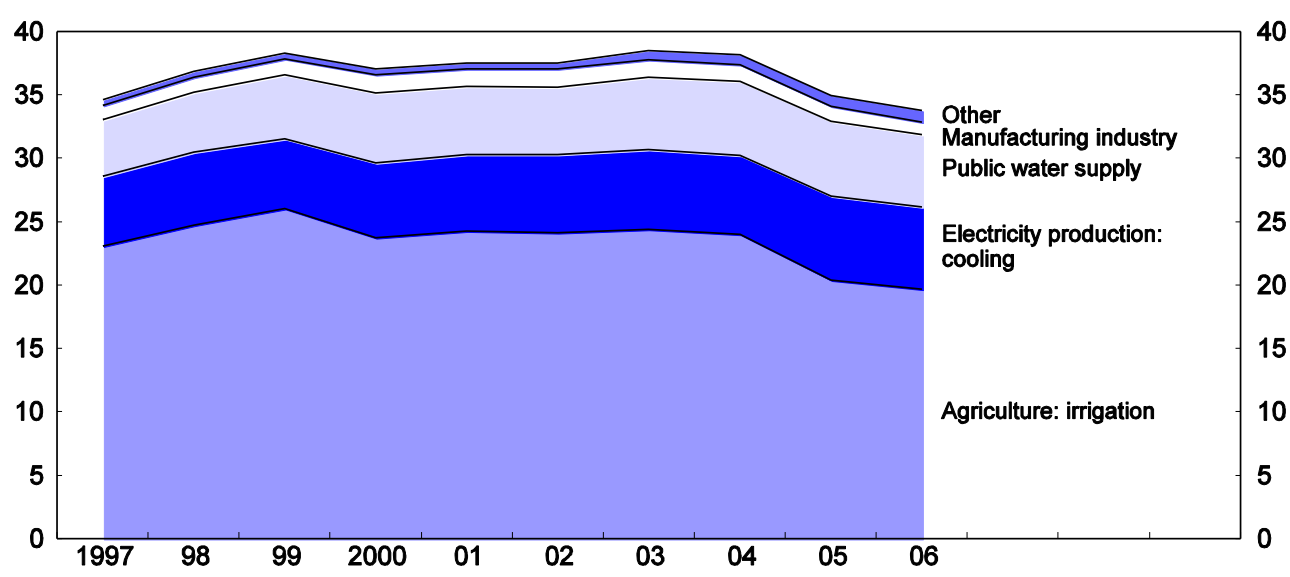

Source: Eurostat (2010), "Environment and Energy", Eurostat database, June.

\section{Some aquifers are overexploited}

Groundwater accounts for around $20 \%$ of total extractions. Groundwater endowment levels are ample, with a storage capacity several times the size of dam capacity. Recharge rates - which determine the renewable resources available - are however typically just a small fraction of the level of reserves (Molinero et al., 2008). Flows into and out of groundwater reservoirs relative to the stocks are much smaller than for surface waters, resulting in average storage of water in groundwater reservoirs of between 100 and 10000 years (Barcelò, 2008). This characteristic makes policies to ensure sustainable use, in terms of both water quality and quantity, particularly important, as overexploitation may have little impact on available resources in the near-term, but may require prolonged corrective action to revert. Furthermore, adequate groundwater levels ensure that rivers continue to flow in dry periods.

Groundwater abstractions have risen over the past decade (Figure 3). As in other semi-arid countries, most of the abstractions are for agricultural purposes. It is especially important for agriculture along the Mediterranean, where much of the most productive agricultural activity is located. A substantial share of groundwater resources is at risk of being overexploited (Figure 4). ${ }^{2}$ Overexploitation has led to saltwater intrusion in some coastal areas (MARM, 2009a), deteriorating water quality. High salinity affects $50 \%$ of groundwater in one of the driest water basins (Júcar), and this share continued to rise in 2009 (OSE, 2009). The government considers that aquifer overexploitation is one of the major risks for reaching the targets of the European Union Water Framework Directive, with almost 38\% of groundwater bodies being at risk of not achieving its quantitative and qualitative targets. This share may yet rise when pending assessments of groundwater bodies are published (Molinero et al., 2008). Observers (such as Custodio et al., 2010) have noted that a strict application of the European Water Framework Directive would lead to the cessation of a significant share of groundwater abstractions.

2. The "quantitatively good state of water resources" is defined as a level of extraction that does not reduce existing reserves and does not generate risks for environmental objectives concerning surface waters. 
Figure 3. Groundwater abstraction by sector

Billion cubic metres

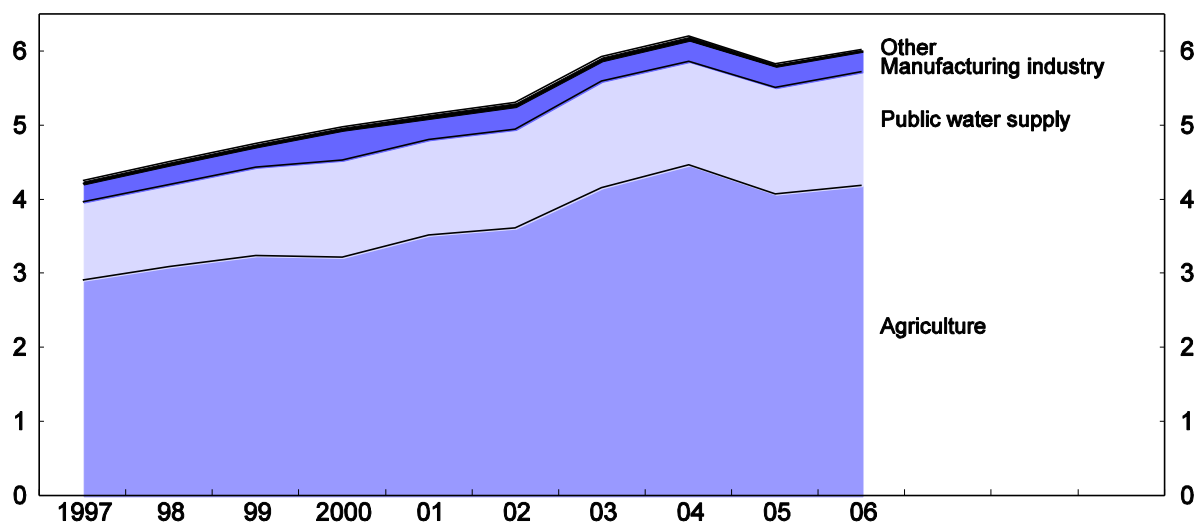

Source: Eurostat (2010), "Environment and Energy", Eurostat database, June.

Excessive groundwater abstractions have reduced wetland areas. These wetlands and their small ponds make a very large contribution to bio-diversity in semi-arid climates. By offering breeding grounds for migratory species they also have considerable international significance. Risks have arisen even in protected National Parks, such as the Tablas de Daimiel, which are now fed by artificial surface water supply. Eighty-seven per cent of wetlands are, moreover, unprotected (García Novo et al., 2010).

\section{Figure 4. Aquifers at risk of not attaining a quantitatively good status ${ }^{1}$}

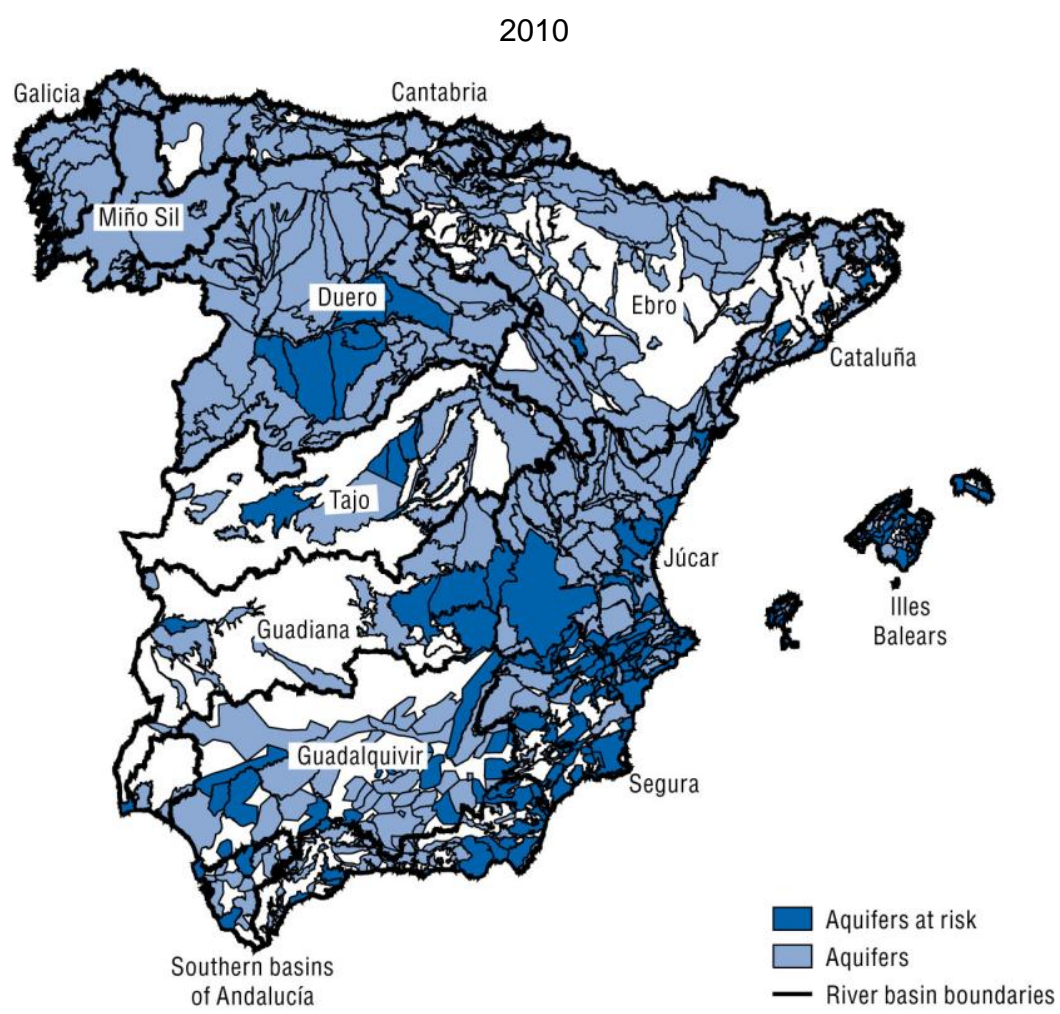

1. The definition "good status" follows the EU Water Framework Directive. A quantitatively good status requires that abstractions do not have a significant impact on related surface water bodies.

Source: Ministerio de Medio Ambiente y Medio Rural y Marino. 
In addition to salinity, nitrate pollution has contributed significantly to groundwater degradation. While $97 \%$ of abstractions for human consumption comply with the nitrate regulations (MARM, 2008b), $25 \%$ of measuring stations reported very high concentrations of nitrates (more than $50 \mathrm{mg} \mathrm{NO}$ per litre) in Spain in 2008. This share is larger than in almost all other European countries for which data are available from the European Environment Agency. ${ }^{3}$ Nitrate pollution mostly reflects diffuse pollution from agriculture and cattle-raising, although the consumption of nitrate-based fertilisers has fallen by about $25 \%$ since its peak in 2003. Moreover, the driest river basins are much more heavily affected by such high concentrations than the national average. The consequences of such pollution for water availability in these basins is also likely to be the severest, as high nitrate concentrations limit the extent to which water reserves can be used for other purposes at low cost, such as urban water supply.

\section{Climate change will further lower the natural supply of water}

Climate change is expected to reduce precipitation and increase the frequency of droughts (Iglesias et al., 2010). The natural availability of water resources through surface run-off, aquifer recharge and rainfall has already fallen by 5\% between 1985 and 2005 (MARM, 2008a). The decline in rainfall has been particularly marked in southern basins, exceeding 10\% between 1947 and 1999 compared to a decline of 5.5\% for Spain as a whole (see Barcelò, 2008 and references therein). According to Barcelò (2008), this observed decline in natural water availability is consistent with projections according to which climatic change causes rainfall to diminish in the Mediterranean region, and in Spain especially markedly so. Rainfall is projected to fall by a further 22-34\% between 1995 and 2060 in Southern river basins. ${ }^{4}$ These are, already today, identified as those being most strongly at risk of overuse of scarce resources. Moreover, these trends will be reinforced by the effects of higher temperatures on evapotranspiration ${ }^{5}$. The government is conducting a detailed sectoral assessment of impacts, vulnerability and adaptation to climate change with special attention to water resources, water demands and coping strategies with the National Plan for Adaptation to Climate Change (MARM, 2009b).

\section{Low water prices hold back the development of unconventional supply sources}

In view of declining natural water availability and the limits to raising the amount of abstracted "conventional" water resources, reused water and desalination have been playing an increasing role. In 2008 the capacity of desalination increased markedly, including with the construction of Europe's biggest plant in Murcia, in south-eastern Spain (MARM, 2008a). The expansion of desalination is a key aspect of the revised National Hydrological Plan (Plan AGUA, Box 1). Spain is relatively well-placed to take advantage of this resource, especially along its long Mediterranean coast where pressures on water resources are particularly strong.

3. This is also true when the comparison is limited to large countries which report a similarly dense network of measuring stations (France, Germany).

4. Guadalquivir, where the decline is projected to amount to $34 \%$, Cuencas del sur, Segura, Guadiana and Júcar.

5. Evapotranspiration denotes the movement of water to the air, for example from the soil (evaporation) and the loss of water through plant leaves (transpiration). 


\title{
Box 1. The revised National Hydrological Plan (2005-2008): Plan AGUA
}

\author{
Actuaciones para la Gestión y la Utilización del Agua
}

The objective of this programme, effective since 2005, is to reorient water policies towards ensuring sustainability of use, in terms of quantity and quality, raise the efficiency in water use and minimise the cost of supply. It recognises the impact of climate change on available water resources as a result of rising temperatures and lower rainfall and aims at making supply less dependent on climatic conditions. The measures focus on the Mediterranean coastal areas where water scarcity is particularly marked. The programme provides 3.9 billion euros of funding for investment projects, of which a third is provided by the European Union. It aims at saving water resources amounting to $1100 \mathrm{hm}^{3}$ (cubic hectometres) annually by fostering demand management, recycling of water and encouraging efficiency in water consumption. The emphasis is on desalination, which provides about $70 \%$ of the resources generated by the programme. Prices of desalinated water are provided at subsidised cost to agriculture. In view of the relatively high costs of desalination, the provision of desalinated water to agriculture risks generating inefficiencies and costs to public finances.

Even so, production capacity in desalination is currently limited to $2.8 \%$ of water abstractions at the national level. Unit costs are a multiple of current prices typically paid for the supply of fresh surface water even in these areas (MMA, 2007a), even though technological progress has allowed the production cost to be reduced by about $50 \%$ over the past ten years according to government estimates. Desalinated water is supplied at subsidised rates. The high energy intensity of the production process may continue to constrain its development as a large scale water resource base and the environmental consequences of the residues of desalination are not yet fully understood. It is therefore considered to be limited to a highly localised contribution to water supply (OECD, 2009).

The potential for recycled water is also relatively promising in Spain, inter alia, because of the proximity of densely urbanised regions to intensive agriculture in dry regions along the Mediterranean. As in the case of desalination, production costs often exceed prices, slowing further development. Recycling contributes a smaller share to water supply than desalination, and is used, for example, to supply public gardens, golf courses and selected irrigated agriculture as well as to recharge aquifers. Technological progress in quality assurance and treatment has been significant, but limitations persist, inter alia reflecting the difficulty of ensuring that quality is adequate in real time for each specific use so as to ensure that it poses no risk, for example, for human health when used in irrigation (Salgot and Folch, 2008). A survey of water experts' views (Terceño-Gómez et al., 2009) shows that the recycling of water resources is considered the most promising option to address scarcity issues from the supply side, well ahead of desalination. ${ }^{6}$ Although cost-reflective prices are a condition for expansion of this sector, there is a case for public research and development (R\&D) support to foster its future development, once cost-reflective water prices are ensured, owing to market failures in private $\mathrm{R} \& \mathrm{D} .^{7}$ There also appears to be a case for $R \& D$ subsidies for wastewater reuse for the purpose of electricity generation (OECD, 2006a).

Overall, the expansion of both conventional and unconventional water supply is subject to limitations, at least at current prices. Hence, effective demand management is crucial in order to make sure that water abstractions are kept within environmentally sustainable limits and made available to priority uses.

6. Cross-basin water transfers were ranked equally high as reuse, by water experts in one basin (Segura).

7. These include the prevalence of the public sector in water supply, in part reflecting natural monopoly characteristics and the inability of businesses to fully capture the gains from intellectual property. Moreover, there may be network effects which may tie private spending to existing technologies. 


\section{Patterns of water demand}

\section{Water use in agriculture}

Most river basins identified as being particularly affected by water scarcity are characterised by intensive irrigation use. ${ }^{8}$ Agricultural use accounts for between 80 and $90 \%$ of water abstraction in basins of the south and in the basins of rivers flowing to the Mediterranean Sea. While some of the water used by irrigated agriculture is reused by other downstream users or diverted to meet environmental needs, a large share is consumed in evapotranspiration (the share being close to the total with modern irrigation techniques). Losses also result in groundwater sources which are no longer economic to pump (OECD, 2010a). For the country as a whole, irrigation accounts for $58 \%$ of total water abstractions and for about $72 \%$ of water abstractions for consumptive water use in 2005 and 2006 (non-consumptive use includes water use for electricity generation or for cooling purposes) according to the most recent published data (see Figure 2). This is a bigger share than in most OECD countries behind only Greece, Turkey and Australia. The share of irrigation in total water consumption may have fallen to $65 \%$ in Spain in 2008, according to an estimate from the Ministry of the Environment, Rural and Marine Affairs. Access to water is fundamental for productivity in agriculture in most of Spain, contributing $55 \%$ to total agricultural value added.

Irrigated surface has continued to expand slowly over the past 20 years, including in recent years, by $4.8 \%$ between 2003 and 2009 (Table 1 and Figure 5). While some new irrigation projects, for example in the Ebro river basin, were maintained in the revised national hydrological plan (2005-08), the government does not expect further expansion. Water abstractions for irrigation remained broadly constant until 2004. These developments resulted in a 9\% reduction of irrigation water application rates between 1990-92 and 2002-04. Water use in irrigation ${ }^{9}$ declined by $12 \%$, on average, between the period 2002-04 and 2008, reflecting modernisation of irrigation techniques as well as drought conditions in 2008, which reduce water availability especially in irrigation (see above). In 2007, when the degree to which dam reservoirs were filled was similar to long-term average levels, irrigation water use was 7\% lower than between 2002 and 2004. Hence an additional reduction in trend water application rates of perhaps similar magnitude as in the period 1990-92 to 2002-04 appears to have occurred after 2004. In some other highincome countries in which the share of irrigation in cultivated land is relatively large or where irrigation accounts for a large share of water consumption (Australia, Denmark, France, Japan and the Netherlands) irrigated surfaces also expanded, although in most cases less than in Spain. Water applications fell more markedly in most of them than in Spain in the period between 1990-92 and 2002-04. In Australia, in particular, water application per square meter fell by almost 50\% (Table 1), from a level above that observed in Spain to a level well below. This occurred without losses in output, raising the productivity of water use.

8. These include the Southern Andalusian basins and the Segura, Júcar, Ebro and Guadalquivir basins according to Terceño-Gómez et al. (2009). Conversely, most river basins characterised by intense irrigation use are affected by dryness, although the basins of the Guadiana and Duero are exceptions.

9. National data on water consumption in irrigation are available from a Survey conducted by the Instituto Nacional de Estadística. These are methodologically not comparable with the data on water abstractions reproduced in Figures 1 and 2. 
Figure.5. Irrigation by type of technique

Thousand square kilometres

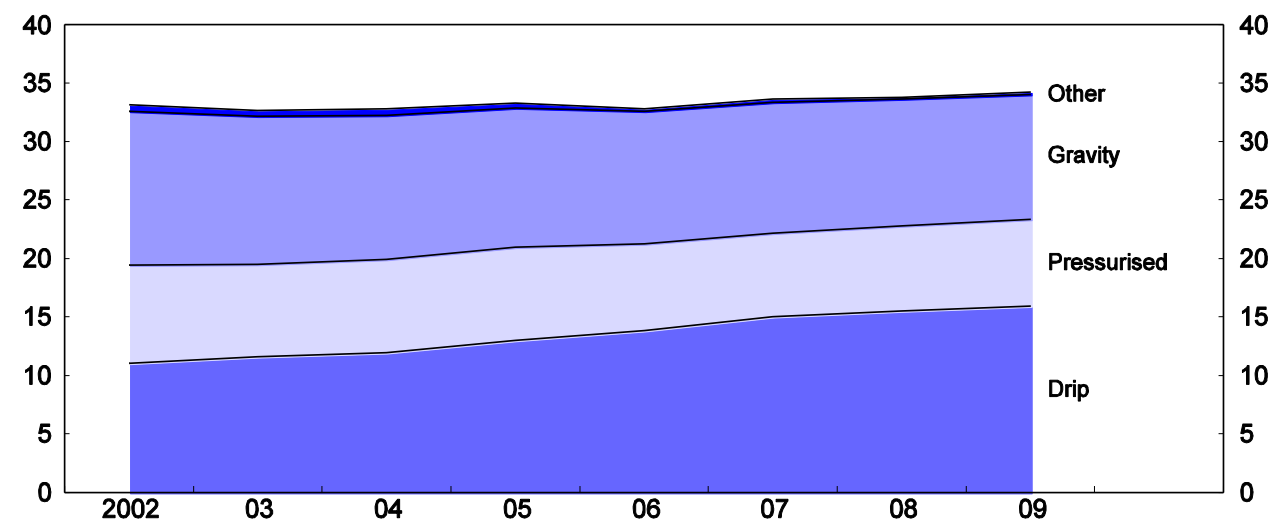

Source: MARM (2010), Análisis de los Regadíos Españoles Año 2009, Ministerio de Medio Ambiente y Medio Rural y Marino.

The trend decline in irrigation water input per hectare was modest and was supported by the modernisation of irrigation techniques. Flood irrigation - the least efficient technique ${ }^{10}-$ has been declining. It accounted for $31 \%$ of irrigated surface and for $42 \%$ of water supplied (MARM, 2009c) in 2007. The more efficient drip and sprinkler irrigation covered $68 \%$ of the surface and accounted for about $58 \%$ of water supplied. The expansion of drip irrigation occurred especially in the southern half of Spain, replacing flood irrigation (MARM, 2010).

There is a risk that water savings obtained from the modernisation of irrigation are used to extend irrigated surface and to switch to more water-intensive produce, offsetting the intended impact of watersaving irrigation technology, which is to free water resources for river flows and the natural habitats they provide, as well as for non-agricultural use. These risks may be reinforced if farmers' incentives are determined by quantity constraints (set in water concessions), with little allocative role of prices. The additional water effectively supplied through more efficient irrigation provides incentives to fully use preexisting water entitlements. The government has devoted substantial budgetary resources to irrigation modernisation. For example, the plan de choque de regadios, introduced in 2006, provided around 2 billion euros of subsidies for such modernisation. While the subsidies were meant to free resources for other uses, including the environment, observers have noted that it is not clear how resulting water savings have been used (Schmidt and De Stefano, 2010). The water savings that result from the Plan de Choque de regadios may however only be observed with a lag. In any case, relatively inefficient flooding techniques are still widespread in international comparison (OECD, 2010a). In the short term, subsidies for irrigation modernisation could be conditioned on reductions in the amount of water designated in concessions, to ensure water savings resulting from the modernisation can be made available to environmental or other economic use.

10. However, in flood irrigation use of land-levelling techniques are increasingly being used. 
Table 1. Irrigation water use in agriculture ${ }^{1}$

\begin{tabular}{|c|c|c|c|c|c|c|c|}
\hline & \multicolumn{2}{|c|}{ Irrigation water use } & \multicolumn{2}{|c|}{ 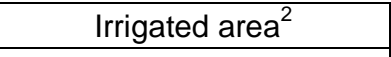 } & \multirow{2}{*}{\multicolumn{3}{|c|}{$\begin{array}{l}\text { Irrigation water application rates } \\
\text { (megalitres per hectare of irrigated } \\
\text { land) }\end{array}$}} \\
\hline & $\begin{array}{l}\text { Share in total } \\
\text { water use } \\
(\%)\end{array}$ & $\begin{array}{c}\text { Growth } \\
(\%)\end{array}$ & $\begin{array}{l}\text { Share in total } \\
\text { agricultural } \\
\text { area }(\%)\end{array}$ & $\begin{array}{c}\text { Growth } \\
(\%)\end{array}$ & & & \\
\hline & $2002-04$ & $\begin{array}{c}1990-92 \\
\text { to } 2002-04\end{array}$ & $2002-04$ & $\begin{array}{c}1990-92 \\
\text { to } 2002-04\end{array}$ & $1990-92$ & $2002-04$ & Growth (\%) \\
\hline Spain & 65 & 2 & 13 & 12 & 7.0 & 6.4 & -9 \\
\hline Australia & 55 & -43 & 1 & 5 & 7.5 & 4.1 & -45 \\
\hline Austria & 5 & 64 & 0 & 0 & 12.5 & 20.5 & 64 \\
\hline Belgium & 1 & . & 2 & 6 & 0.5 & 1.5 & 189 \\
\hline Canada & 9 & 20 & 2 & 20 & 3.5 & 3.6 & 1 \\
\hline Czech Republic & 1 & -24 & 0 & -54 & 0.7 & 1.2 & 64 \\
\hline Denmark & 25 & -33 & 17 & 3 & 0.6 & 0.4 & -35 \\
\hline Finland & 2 & 100 & 3 & 0 & 0.3 & 0.6 & 100 \\
\hline France & 15 & 3 & 9 & 24 & 2.3 & 1.9 & -17 \\
\hline Germany & 3 & -29 & 3 & 1 & 3.3 & 2.4 & -29 \\
\hline Greece & 87 & 33 & 16 & 24 & 4.8 & 5.1 & 8 \\
\hline Hungary & 3 & -65 & 3 & -22 & 2.3 & 1.0 & -55 \\
\hline Italy & 37 & . & 17 & 0 & . & 7.7 & . \\
\hline Japan & 65 & -4 & 50 & -8 & 20.6 & 21.4 & 4 \\
\hline Korea & 58 & 8 & 46 & -10 & 14.3 & 17.4 & 22 \\
\hline Mexico & 74 & -10 & 6 & 2 & 9.9 & 8.7 & -12 \\
\hline Netherlands & 1 & -50 & 29 & 1 & 0.3 & 0.2 & -51 \\
\hline New Zealand & $\ldots$ & $\ldots$ & 2 & 14 & $\ldots$ & $\ldots$ & . \\
\hline Poland & 1 & -77 & 1 & 0 & 3.7 & 0.9 & -77 \\
\hline Portugal & 61 & -7 & 16 & -4 & 8.9 & 8.6 & -3 \\
\hline Slovak Republic & 4 & -69 & 3 & -76 & 0.5 & 0.7 & 31 \\
\hline Sweden & 4 & -8 & 2 & 12 & 2.1 & 1.7 & -19 \\
\hline Switzerland & $\ldots$ & $\ldots$ & 2 & 0 & . & . & . \\
\hline Turkey & 87 & 84 & 13 & 33 & 4.8 & 6.6 & 39 \\
\hline United Kingdom & 1 & -44 & 1 & 3 & 1.0 & 0.6 & -46 \\
\hline United States & 40 & 0 & 5 & 8 & 9.0 & 8.4 & -7 \\
\hline EU15 & 27 & 4 & 10 & 10 & 3.6 & 3.4 & -6 \\
\hline OECD & 43 & 6 & 4 & 8 & 8.0 & 7.5 & -7 \\
\hline
\end{tabular}

1. Periods covered vary considerably across countries as do the countries included in the zone aggregates. See figure 2.2 of Sustainable Management of Water Resources in Agriculture for detailed information.

2. Covers areas with irrigation infrastructure, even if the area is not actually irrigated.

3. Total water use covers total water abstractions for public water supply, irrigation and manufacturing industry including cooling.

Source: OECD (2010), OECD Review of Agricultural Policies: Israel 2010 and Sustainable Management of Water Resources in Agriculture.

The differences in water productivity across crops grown in Spain are large (Figure 6), 75\% of value added generated in irrigated agriculture consumes just $9 \%$ of irrigated water (Table 2). The abundant use of irrigation water for crops characterised by low value added and the resulting low productivity of irrigated water is somewhat more marked in those river basins in which water scarcity is less of an issue. However, some of the basins facing the severest scarcity also exhibit substantial water consumption to irrigate low- 
productivity crops. ${ }^{11}$ In the river basins of Segura, Ebro, Júcar and Guadalquivir more than a third of irrigated water generates a net operating surplus worth less than 20 cents per cubic meter. These water basins are also characterised by particularly intensive irrigation for crop-oriented production of meat and other industrial products supplying the domestic market, which the government considers appropriate, inter alia to maintain employment and the rural environment.

Figure 6. Productivity, water use and value added of irrigated agriculture ${ }^{1}$

Gross value added at market prices in euros per cubic metre of water consumed, 2001/02

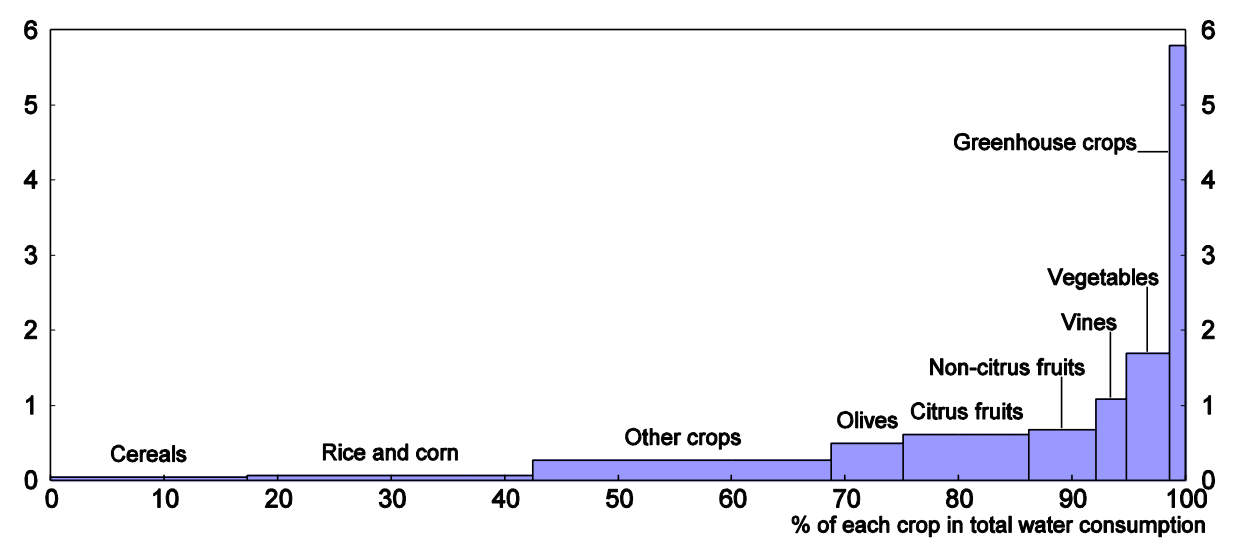

1. Each rectangle area is proportional to the share of each crop in the value added of irrigated agriculture.

Source: MMA (2007), El agua en la economía Española: situación y perspectivas, Ministerio de Medio Ambiente.

Groundwater-irrigated agriculture makes more productive use of water than surface water-irrigated agriculture. This can be attributed to more stable supply, allowing farmers to earn a more certain return on investments from water-saving irrigation technology, as well as to the fact that groundwater abstractions are mostly private, so farmers have to pay for the full extraction cost, which is higher than prices paid for surface water (Molinero et al., 2008).

The cultivation of crops which generate low value added relative to their water needs (such as cereals) is typically characterised by low efficiency in irrigation, i.e. a more extensive use of irrigation techniques that supply more water to the land than the crops require (such as flood techniques). For example, Maestu and Gómez (2010) show that average irrigation efficiency in the production of low value added crops is often below $70 \%$. By contrast, cultivation of high value added crops achieves efficiency rates of $90 \%$. This situation is also likely, to some extent, to reflect the incentives generated by quantity constraints and the limited allocative role of prices: incentives to raise the technical efficiency may therefore only be strong when the value added generated by additional water input is high. More reliance on market signals, such as cost-reflective water pricing and water trading, would help to generate incentives to use water-saving technology in all agricultural production (see below).

11. Terceño-Gómez et al. (2009) note that assessments about which basins are considered subject to the most severe stress differ depending on the approach used. They therefore conducted a survey of water experts to generate a consensus view. Their survey includes information on the evolution of water reserves and water demand in recent years, as well as projections of water supply and demand. The results indicated that the river basins subject to most stress are Cuencas del Sur, Segura, Baleares, followed by Ebro, Júcar, Cataluña, Guadalquivir and Tajo. 
ECO/WKP(2011)9

Table 2. Water consumption in irrigation by river basin and profitability range

Hundred cubic metres

\begin{tabular}{|c|c|c|c|c|c|c|c|c|c|}
\hline $\begin{array}{l}\text { Net operating surplus } \\
\text { per cubic metre }\end{array}$ & $<0.02$ & $0.02-0.2$ & $0.2-0.4$ & $0.4-0.6$ & $0.6-1.0$ & $1-3$ & $>3$ & Total & $\begin{array}{c}\text { Water } \\
\text { scarcity } \\
\text { rank }^{2}\end{array}$ \\
\hline $\begin{array}{l}\text { Southern basins of } \\
\text { Andalucía }\end{array}$ & 97 & 42 & 38 & 11 & 39 & 11 & 93 & 331 & 1 \\
\hline Segura & 54 & 272 & 174 & 271 & 171 & 51 & 19 & 1013 & 2 \\
\hline Ebro & 401 & 1499 & 768 & 675 & 45 & 23 & 0 & 3410 & 3 \\
\hline Júcar & 119 & 581 & 391 & 583 & 206 & 12 & 8 & 1900 & 3 \\
\hline Guadalquivir & 733 & 1151 & 1012 & 443 & 155 & 21 & 16 & 3532 & 5 \\
\hline Tajo & 299 & 463 & 16 & 47 & 24 & 104 & 0 & 954 & 6 \\
\hline Guadiana & 1001 & 496 & 78 & 256 & 62 & 157 & 0 & 2051 & 7 \\
\hline North & 1 & 2 & 0 & 8 & 0 & 0 & 0 & 12 & 8 \\
\hline Canarias & 7 & 1 & 0 & 0 & 36 & 32 & 0 & 76 & 9 \\
\hline Duero & 495 & 1202 & 334 & 113 & 11 & 1 & 0 & 2158 & 9 \\
\hline Total & 3208 & 5710 & 2812 & 2407 & 751 & 412 & 137 & 15437 & . \\
\hline$\%$ of consumption & 21 & 37 & 18 & 16 & 5 & 3 & 1 & 100 & . \\
\hline$\%$ of gross value added & 0 & 5 & 11 & 9 & 9 & 20 & 47 & 100 & $\ldots$ \\
\hline
\end{tabular}

1. Gross production value net of intermediate input, labour, capital cost and taxes. Guadalquivir includes Guadalete and Barbate.

2. According to Terceño-Gomez et al. (2009).

Source: MMA (2007), El agua en la economía Española: situación y perspectivas, Ministerio de Medio Ambiente and TerceñoGomez, A., J.M. Brotons-Martínez and J.A. Trigueros-Pina (2009), "Evaluación de las necesidades hídricas en España" (Assessment of Water Needs in Spain), Ingeniería hidráulica en México, Vol. 24, No. 4, Instituto Mexicano de Tecnología del Agua.

The European Union's Common Agricultural Policy (CAP) has some influence on these water use patterns. Subsidies under the CAP are still provided for crops which require large volumes of water, such as cereals. Several reforms of the CAP $(1992,2003)$ have decoupled subsidies from production and have introduced environmental and nature protection regulation. Subsidies have also been made conditional on the adoption of good agricultural practices. Nonetheless, 25\% of subsidies in Spain remain coupled to production, encouraging inefficient use of water (Aldaya et al., 2010). These subsidies remain available for irrigation projects developed before 1991 - hence most area under irrigation today. These subsidies should be removed, especially in river basins subject to structural water scarcity, in the interests of more efficient agriculture and water use.

Spain exports high value added agricultural output with low virtual water content, ${ }^{12}$ such as citrus fruits, vegetables or olive oil, while it imports water-intensive and low value added crops such as cereals, although domestic production of the latter remains significant. Spain also exports livestock products, which are characterised by a high virtual water content, but this largely reflects the use of water-intensive crops as inputs, which are tradable. Spain's agricultural sector is a net importer of virtual water flows, appropriately, for its climate, but less so than Italy, on a per capita basis. ${ }^{13}$

\section{Other water uses}

Households account for about two thirds of abstractions for urban public water (about $10 \%$ of the total). Urban water supply increased relatively strongly, mostly related to both increases in per capita income - for example, on account of publicly provided urban amenities, such as parks - while population

12. Virtual water content measures the water input required for producing crops.

13. Data from 1997 to 2001 presented by Aldaya et al. (2010) and references therein. 
growth has played a smaller role (Maestu and Gómez, 2010). These water uses stopped growing in 2002 and fell by $7 \%$ between 2004 and 2008, a development which is only in part related to drought conditions. ${ }^{14}$ In any case, per capita urban water supply remained considerably higher than in most other European countries. ${ }^{15}$ The urbanisation process has led to increased concentration of water demand along the Mediterranean coast, where scarcity is more marked. Indeed, within Spain, population growth has been the strongest in some of the driest water basins (MMA, 2007b). In international comparison, per capita household consumption is among the highest in the OECD (OECD, 2006b) ${ }^{16}$ Water use by households and services is considerably higher than in most other European countries according to recent data from Eurostat. In view of the role of per capita income, urban water demand may be expected to continue rising if prices do not rise significantly in real terms.

Water demand pressures have also grown in recreational activities linked to tourism, although these are estimated to account for less than $1 \%$ of water abstractions (MMA, 2007b). The financial return on water is often higher than on many crops. The tourism industry is estimated to contribute $11 \%$ to Spanish GDP. It is geographically highly concentrated and has become a fundamental economic activity in some regions along the Mediterranean.

Gross hydropower production is estimated at about 2.5\% of GDP per year (MMA, 2007b). Although its water demand is non-consumptive, it may compete with other uses of water, such as agricultural use, which is often supplied by dam reservoirs. Industrial water abstractions are relatively low per capita in comparison to other OECD countries.

\section{Characteristics of the institutional framework}

The river basin authorities (RBAs) are in charge of surface and groundwater management. Their activities are overseen and, to a considerable extent, funded by the central government for those river basin authorities covering the territory of two or more regions (Box 2). This institutional framework is appropriate, as most water demand must be satisfied from resources supplied within the same river basin. Cross-basin water transfers raise the cost of supply significantly and can have a substantial environmental impact (see e.g. Barcelò, 2009). Several cross-basin water transfers exist and fall under central government competence.

The RBAs have a high degree of autonomy and partly finance themselves through the revenues from water service fees and charges. Users play an important role, mostly through user associations, as their representatives (the users' assembly) directly participate in some management tasks and elect members of RBA decision-making boards, contributing a third of their members. In most RBAs, consumptive users, especially from the irrigation sector, dominate the users' representation, reflecting their large weight in consumptive water use. Representation of environmental, recreational use or of the scientific or consumer protection associations is often absent. This may create a risk of making RBAs vulnerable to regulatory capture by incumbent, dominant water users. ${ }^{17}$ Observers have argued that the RBAs appear to lack staff trained to manage hydrological, ecological and economic issues of water, reflecting their traditional orientation towards the engineering tasks related to expanding and maintaining water supply infrastructure (see e.g. Varela Ortega and Hernández-Mora, 2010; Custodio et al., 2010). The participatory approach in

14. Urban water supply also fell slightly in 2007, when dam reservoir capacity recovered.

15. In 2006, close to twice as high as in Greece or Portugal, and 50\% higher than in the Netherlands.

16. OECD (2006b) shows data from around 2000.

17. Varela Ortega and Hernández-Mora (2010) mention the users' assemblies of the Ebro, Guadiana and Tagus RBAs, in which irrigators contribute at least about half of user representatives, while the other groups are hardly represented. They contrast this with the Catalonian user assemblies. 
the RBAs should be widened to a wider set of stakeholders, such as scientists, representatives of institutions protecting local ecosystems and the leisure services these provide. Such steps may also help to better incorporate the European Union Water Framework's objectives, which include the establishment of a good environmental status for water bodies and require the inclusion of environmental costs of water use in pricing.

\section{Box 2. Assignment of responsibilities}

The constitution makes the central government responsible for all water policy concerning resources shared by more than one autonomous community. It hence oversees those river basin authorities (RBAs) which straddle the boundaries of two or more autonomous communities. In these cases, it funds transport and supply infrastructure, in part through the RBAs. It sets policy priorities, which are subject to EU directives, in the national hydrological plans covering multi-year periods. The latest National Hydrological Plan, from 2001, was amended in 2004 with the plan AGUA (see below).

The National Water Council, which represents national and regional governments as well as representatives of user associations (agriculture, local governments), scientists and environmental non-governmental organisations, provides recommendations on all policies affecting water resources nationally. Central and regional governments usually hold a majority.

River basin authorities (RBAs) (organismos de cuenca) manage water resources (including groundwater since 1986) and wastewater releases into natural water streams as well as public storage and long-distance transport infrastructure. They develop and monitor river basin plans and administer water resources, including by granting concessions. The RBAs have a high degree of organisational, functional and budgetary autonomy. In river basins covering the territory of more than one region a Competent Authorities Committee coordinates all water-relevant policies of the governments and the RBA.

Regional governments are in charge of natural resources, agricultural policies, subject to European Union directives and central government guidelines, as well as of land-use planning. They participate in some cases in the urban supply of water as well as the collection and treatment of wastewater. They fund transport and supply infrastructure, generally for water resources which are not shared across regions, although some recent regional constitutions specify the creation of reserves, drawn from shared river flows. They have oversight over those river basin authorities which are in charge of river flows that do not straddle regional boarders.

Local governments are responsible for the collection and treatment of wastewater and the supply of drinking water. They can offer these services either themselves or through licensed public or private enterprises.

Users are required to create user associations when they share a common concession or the same outlet. They can also be obliged to do so if the aquifer they exploit is declared overexploited. The associations establish norms for distribution and control, regulate the use and maintenance of shared hydraulic systems, organise the shared payments and resolve problems among members. They play an important role in the RBAs, to which they assign members in the users' assembly, which in turn elects at least a third of the members of key decision-making units in the RBAs, including the governing board.

Some autonomous regions have developed statutes which claim water resources from shared river basins, which runs counter to this assignment of responsibilities. Since the statutes are approved through legislation at the central government level, there is a risk that such provisions encourage regional decisions on water use which do not take into account the impact on other regions. Generally, competences over water resources which are to a substantial extent shared across regional governments should remain clearly assigned to the central government level and the corresponding river basin authorities. ${ }^{18}$

18. In the case of a few RBAs, only a small share of water resources of a basin is shared and the assignment of competencies to one regional government is not problematic (Duero and Guadalquivir). 


\section{Pricing of water services has important allocative and funding roles}

Competition for the use of water resources for human consumption, productive uses, and the support of ecosystems are a challenge for water policies throughout OECD economies. Theoretical and empirical research suggests that price instruments are more cost-effective than implementing non-price conservation programmes in managing demand and need not have more adverse consequences in terms of income redistribution (Olmstead and Stavins, 2008, provide a review of theoretical arguments and policy experience). As with the use of other scarce environmental resources, this is because prices give consumers most freedom to tailor their consumption response, achieving water savings in a way that maximises welfare gains and minimises cost. The demand for water is price-elastic, even in urban use, provided prices rise above minimal levels. For example, a study by the Ministry of Economy and Finance estimated the price elasticity of drinking water demand at -0.6 and the income elasticity at 0.4 in the Júcar River Basin. This estimate may need to be interpreted as a lower bound, as estimated water demand elasticities do not capture long-term responses in full (Garrido and Calatrava, 2009). Indeed, there is evidence that urban water consumption has grown less in those regions which have raised prices more strongly (MMA, 2007b). Concerning agricultural water use, Israel ${ }^{19}$ offers an example where substantial increases in water prices (by 65\% between 1998 and 2008; OECD, 2010b) have allowed water consumption to fall, while the quantity of crops produced remained steady. Moreover, in Spain, in view of the large water productivity differences observed across different agricultural activities, opportunities for shifting to less waterintensive crops may well arise.

\section{Water saving incentives have been introduced in tariff structures}

Progressive tariff structures, which set higher volume tariffs for higher volumes of water consumed, have become the norm in urban and industrial water use. Especially in urban use, this tariff structure creates incentives to save water while protecting basic water needs, especially for low income households. Prices for water services to households have risen modestly in real terms, by about $12 \%$, between 2001 and 2009, although in some of the regions most strongly affected by water scarcity water prices have risen more strongly. A similar development has been observed for industrial prices. Nevertheless, water supply and sewerage service charges for households are lower than in most OECD countries (Figure 7). Nonetheless, researchers consider prices of water used by households to recover costs to a larger extent than prices of water used by irrigators (Garrido and Calatrava, 2010; see below).

Figure 7. Unit prices of water and wastewater services to households ${ }^{1}$

US dollars per cubic metre, 2008

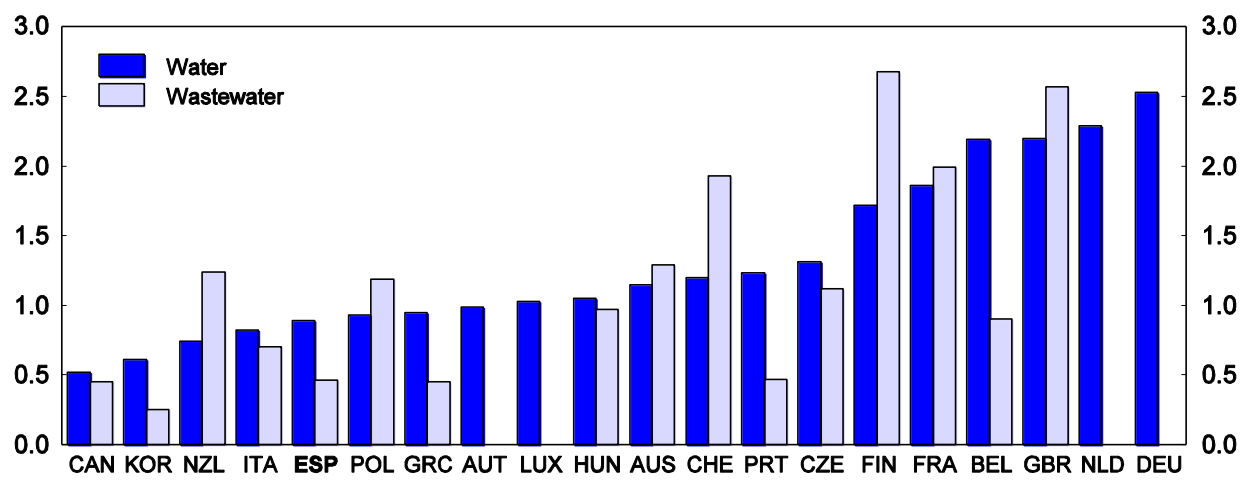

1. Unit prices including taxes. For Belgium and the United Kingdom, data shown are averages of regional data available. Source: OECD (2010), Pricing Water Resources and Water and Sanitation Services.

19. The statistical data for Israel are supplied by and under the responsibility of the relevant Israeli authorities. The use of such data by the OECD is without prejudice to the status of the Golan Heights, East Jerusalem and Israeli settlements in the West Bank under the terms of international law. 
In agriculture, water pricing based on surface irrigated is still widespread in gravitation-based irrigation. However, in May 2009, a ministerial order introduced the obligation (to be implemented gradually), to meter all water consumption, regardless of the type of consumptive use, although the obligation may not apply to individual final consumers. The government aims to introduce two-part tariffs, with a surface component to reflect fixed infrastructure costs and a per-unit volume component in irrigation on the basis of this newly introduced obligation. Indeed, as pointed out by Garrido and Calatrava (2009), the widespread introduction of metering and volume-related charges is crucial to create incentives to use water economically in the irrigation sector. Metering and volume related charges should be widely introduced, as planned by the government. The introduction of water meters requires time and a substantial investment. The government also removed the subsidised tariffs for electricity in irrigation, leading to an increase of costs by $60 \%$, which resulted in some irrigation being abandoned. This measure is appropriate as subsidies for energy, by reducing pumping costs, contribute to excessive extraction of water (OECD, 2009), especially in the case of groundwater, which has proven difficult for the authorities to control (see below). There has been pressure to reduce the impact of the deregulation on farmers' irrigation costs, although the share of irrigation costs to total costs in farming is often modest, especially where water productivity is relatively high. Tariffs for electricity in irrigation should reflect electricity supply costs in full, as originally intended by the government.

\section{Current legislation prevents prices from fully reflecting the cost of supplying water}

Water pricing in Spain follows complex rules, set out in national legislation, with different charges for consumptive and non-consumptive use. ${ }^{20}$ By law, prices must cover but not exceed the operating and capital costs from the operation of government-funded supply infrastructures (transport, storage and treatment) as well as administrative costs to the extent that they are directly related to the operation of these infrastructures. Charges for industrial and residential effluents are also set in national law, graded according to the degree of pollution (Garrido and Calatrava, 2010).

While the recovery of costs that results from the scarcity of water ${ }^{21}$ is particularly relevant for a country with a semi-arid climate, scarcity and environmental costs cannot be included in water prices over and above operating and capital costs. For example, prices for users drawing on a common water resource pool (such as users located in the same water basin) should, in principle, be priced according to the marginal cost of the costliest water supply source. This may, for example, play a role in those regions where desalination is playing an increasing role in water supply. As marginal costs exceed average costs, prices set according to efficiency principles generate scarcity rents, which current legislation does not permit. The recovery of these costs is also generally required by the EU Water Framework Directive, although it allows exceptions, and the recovery of such costs is thus far not widespread international practice. One way in which scarcity of water could be reflected in water prices would be to link them to indicators of water scarcity in the relevant river basins. Indeed, a system of such indicators that allows the development of water resources to be determined in real time has been developed with the implementation of the latest National Hydrologic Plan. Current legislation does not create any room for charging for environmental costs from water abstractions that result from changes in water flows, river morphology, or water quality and their impacts on human health and ecosystems, although this is required by the European Water Framework Directive. Legal limitations on water pricing which impede prices from reflecting scarcity and environmental considerations should be eliminated. Methods will have to be developed to

20. A few regions (such as Catalonia), whose river basins are not shared with other regions, are not covered by national legislation and have their own pricing rules.

21. The 1999 amendment of the Water Law introduced a factor of 0.5 to 2 , to be applied to tariffs reflecting financial costs, depending on whether consumption exceeds or is below reference levels. But these reference levels are likely to be determined with respect to individual concessions and do not reflect scarcity of the resource. 
determine valuations for the environmental impact of water abstractions. It is important to improve transparency in water charging, so as to provide information of the different costs involved in the calculation of tariffs, including environmental and scarcity costs.

While pricing mechanisms exist for point pollution to surface waters, none are in place for diffuse pollution of groundwater. One option could be to introduce a tax on the consumption of such pollutants, for example in fertilisers. However, experience with taxes on fertilisers suggests that they must form part of a general policy mix, as the tax may need to be levied at very high levels to be effective in reducing pollution. A tax on nitrogen or on phosphorus would more closely address the environmental externality. Such a tax requires each farm to keep a nutrient budget. This has been done in the Netherlands, with the tax levied on the surplus of nitrogen or phosphorus. Specific action programmes for designated areas vulnerable to nitrate contamination could complement such a measure. Since the consequences of diffuse pollution may be more severe in the driest basins, subsidies to support pollution minimising cultivation, especially in such basins, could help lower nitrate contamination.

Improvements may also need to be considered concerning the recovery of capital costs of infrastructure used in the provision of water services. The legal provisions make it difficult to recover some subsidies in water prices. Moreover, some benefits of infrastructure (such as dams) are considered to have public good characteristics, notably with respect to flood control, resulting in part of the cost not being reflected in prices (MMA, 2007a). While such public good characteristics of infrastructure justify that associated costs are not born in full by water consumers, rigorous criteria to attribute infrastructure to different uses have not been established (CICCP, 2010). In some cases, capital costs are considered to have been repaid in full by past users, so that none are imputed to current users. A government report (MMA, 2007b) points out that low prices reflect the lack of replacement investment in infrastructure in water supply and treatment. Some management costs of the river basin authorities are not included in the cost calculation (MMA, 2007a). The legislation prescribes that capital costs be calculated by applying an interest charge of $4 \%$ as well as amortisation rates to nominal historic costs of infrastructure, with only partial adjustment to past inflation. ${ }^{22}$ An interest rate of $4 \%$ appears low if applied to nominal historic prices. Although the lifetime of such infrastructures is long, the effect of too low interest rates may not be large, in part because of the relatively modest share of upstream infrastructure capital cost in total cost in irrigation. $^{23}$

According to an analysis by the Ministry of Environment (MMA, 2007a), cost recovery is, nonetheless, on average, close to $90 \%$ in both urban and agricultural use, albeit with significant regional and local variation. A recent study (Calatrava and Garrido, 2010) estimates that cost recovery is $45 \%$, on account of low recovery of capital costs. A wide gap in the recovery of costs of services to supply water has also been diagnosed by the Spanish College of Infrastructure Engineers (Colegio de Ingenieros de Caminos, Canales y Puertos, CICCP, 2010). The discrepancies among estimates suggest that transparency of cost accounting needs to improve. In any case, the revenues generated by current prices are insufficient to fund replacement investment. The risk that needed replacement investment is not carried out is heightened by current tight budgetary policies. Pricing of water services on the basis of historic costs could also encourage stakeholders to oppose replacement investment, as such investment would lead to higher fees later on. Indeed, only a small part of spending by the river basin authorities is recovered. Their revenues from the different charges (excluding charges for effluents) do not even cover current spending

22. Historic prices are only revalued by the difference between a reference interest rate and $6 \%$, provided the reference rate is above $6 \%$. For example, this has never been the case since 1997

23. On the other hand, Garrido and Calatrava (2009) argue that raising the imputed interest cost on past capital expenditure from 4 to $5 \%$ reduces estimated cost recovery rates substantially. 
on wages, goods and services and financial charges in full, leaving all capital spending uncovered. ${ }^{24}$ The method of calculating capital costs should be reviewed and full cost recovery ensured. Consideration should be given to allow prices to generate sufficient revenue to fund replacement investment. Prices should also fully take into account administration and management costs, even if they cannot be attributed to specific infrastructure. Criteria on the attribution of costs to services with public goods characteristics, such as flood control, should be harmonised according to transparent criteria. Higher, cost-reflective prices for irrigation water would also go a long way in reducing groundwater pollution through the use of chemicals. Numerous studies have shown that more efficient water use reduces agricultural pollution (e.g. Calatrava and Garrido, 2010).

Data on water services and all related costs need to be accessible nationwide in order to allow an assessment of the extent to which these costs are reflected in prices of individual sources. A recent government report (MMA, 2007a) shows that access to these data needs to be improved. Such steps could help reduce disparities in the assessment of costs and improve acceptance of changes in prices by the general public.

\section{Benchmark regulation of water services offers substantial advantages}

Steps to improve the accessibility of data on water services and their costs would also help introducing the benchmarking of costs and quality of provision by water utilities. Using the costs and quality standards achieved by other service providers, in order to set regulated prices for water services of each service provider, generates incentives to improve quality and reduce costs, including through watersaving investments. These incentives are lost if price regulation is based on each provider's own costs. Benchmark regulation is especially attractive if there are numerous local service providers, as is the case, for example, for urban water supply and sewerage services.

The scope for improving the efficiency of service provision appears to be significant. For example, the Spanish College of Infrastructure Engineers has pointed out that costly, modern water treatment capacity is often poorly utilised and managed, resulting in unnecessary pollution. The long-run costs resulting from such inefficiencies are large, as, in the long run, pollution is considered to be the main factor contributing to future increases in the cost of producing drinking water, alongside climate change (OECD, 2006a).

While benchmark competition does not require privatisation of service providers, ${ }^{25}$ it makes the provision of services by private enterprises more attractive because it can harness their profit maximisation motive for the reduction of costs and improvements of quality of service while ensuring that monopoly rents do not accrue to service providers. Thereby, it can also help mobilise private investment for water infrastructures at a time when public investment is being cut back while investment needs are large.

Benchmarking is increasingly used to raise efficiency in water services, for example in the United Kingdom and Australia, on the basis of a manageably limited list of cost and quality indicators. A system of benchmarks for water services provided by utilities has also been developed by the American Water Works Association (OECD, 2006a). Availability of data on water service provision and related costs nationwide should be ensured. Consideration should be given to use such data to benchmark costs of service providers and regulate prices and quality of service accordingly.

24. For example, in 2007, the RBAs' current expenditure amounted to 210 million euros, revenues, excluding charges for effluents, to about 180 million euros. Capital expenditure amounted to about 710 million euros.

25. Studies of efficiency of municipal services have not revealed efficiency advantages of private enterprises, if anything the opposite appears to be the case (Benito et al., 2010). 


\section{The concessions regime and the trading of water rights}

Consumptive water use requires a government concession which can be granted for up to 75 years, provided the water is considered in the public domain, which is true for all surface waters and part of groundwater resources (see further below). They need to respect the strict priority the law assigns to urban use. Revisions of concessions are possible under some circumstances. The RBAs grant these concessions for free. For irrigation purposes the volume of water made available by these concessions depends on perhectare quotas and available water resources and so are variable over time. The initial water allocation is hence based on the basis of historically determined water rights and irrigated surface. Economic criteria do not play an important role, although there is some limited scope for changing the initial assignment of water rights through trading (see below).

\section{Regulation limits trading of water concessions}

Markets for water entitlements cannot alone resolve environmental, economic and social issues involved in the allocation of water across different uses (OECD, 2009). Effects which are external to the trading partners occur, for example, as a result of alterations in river flows, and the relatively high cost and lack of transport infrastructure limits the scope for trade. The availability of water at different points in space and time has an impact on valuations, further increasing transaction costs (see e.g. Dalhuisen et al., 1999). Nonetheless, comprehensive water markets, including for the transfer of longterm water rights, have developed, for example, in the south-west of the United States and in Australia where they have delivered efficiency gains worth several billion dollars (Quentin Grafton et al., 2010). They have helped to allocate increasingly scarce water supplies among competing agricultural, urban, and environmental uses and have encouraged water users to make water-saving investments.

Informal trading of water is common in Spain, especially in agriculture. These trades rely on trust among farmers, are mostly temporary and are typically limited to farmers within an irrigation community, which often holds a water concession shared by its members (Box 4.1). There are virtually no permanent trades with respect to surface water - which is the predominant source - because, unlike groundwater, surface water rights are by law tied to land ownership. Formal trading of water rights beyond the users sharing one concession was allowed in 1999 but remains rare. For example, in the Segura Basin formal water trading between 2001 and 2005 amounted to less than $1 \%$ of total water consumption (Garrido and Calatrava, 2010). Some RBAs have also have set up water banks to encourage the trading of seasonal water rights during drought periods with some success, helping to avoid water rationing in such periods. In these cases RBAs tender water use rights, acting as an intermediary between potential sellers and buyers and have purchased water rights to reach environmental objectives, such as restoring downstream river flows. While such schemes may well be the most cost-effective intervention to improve water supply for environmental purposes (see e.g. OECD, 2008), prices paid appear very high in some cases. ${ }^{26}$

The trading of water rights over longer periods of time is subject to regulatory limitations that have impeded market development (Ariño Ortiz and Sastre Beceiro, 2010). For example, the Water Law generally allows owners to sell water rights for uses considered to have at least the same priority, as assigned by the Law, as their own. This provision prevents urban suppliers, for example, from selling water rights to farmers. Trades are capped to the seller's consumption in the years preceding a deal, which may prevent sale of underused concessions. The law also excludes the participation of dealers or traders in the market. Yet the experience on the Canary Islands, where the provisions of the Water Law do not apply and where water markets flourish, suggests that traders have played an important role in brokering mutually beneficial trades. The experience of the Canary Islands also suggests that regulated third party

26. Garrido and Calatrava (2010) report a purchase price of effectively 2-4 euros per cubic meter, a multiple of even the highest prices paid for water by farmers. 
access to transport infrastructures, with regulated tolls, may also facilitate trades at the local level. At present, regulated third party access is only ensured for publicly-owned infrastructure. The binding nature of the restrictions came to the fore during the last drought period, 2005-06, when the government brokered the transfer of water rights across river basins, but had to issue specific enabling legislation in order to do so.

Water banks could be extended to other river basins and restrictions on the trade of water concessions should be eased. For example, caps on sales established on the basis of past consumption could be reviewed, the participation of dealers could be allowed and regulated third-party access to private infrastructure introduced. The requirement not to sell water to users considered to be of lower priority in the law could be reconsidered. On the other hand, owing to the environmental effects that trades may have on parties that are external to the trading partners, trades will need to remain subject to control by the RBAs. In practice, the subsidised rates at which water is made available to farmers in many cases could generate difficulties, because some farmers could be tempted to cash in the present value of the subsidy over the whole period over which a water entitlement is sold, which may be politically undesirable.

Auctioning of newly granted concessions, as well as of concessions which expire could help ensure that water is allocated to its most productive use from the outset. Tendering of water rights could also include non-price criteria in the selection process, such as the implications of water usage for water quality or other environmental impacts. Auctioning and tendering would avoid the inefficiency that results from the allocation of concessions on the basis of past use ("grandfathering") and which may be prolonged by the inherent difficulties in the trading of water rights. It would also ensure that water prices would reflect scarcity as required by the EU Water Framework directive. Moreover, as in the case of other environmental resources, such as greenhouse gas emission permits, auctions generate revenues without recourse to distortive taxation. For example, such revenues could be used to fund the purchases of water rights for environmental objectives which are currently paid for from tax revenues. Auctions could also be applied to non-consumptive uses, such as electricity generation. Hydroelectric generation benefits from rents from the free utilisation of water which could be appropriated by government. ${ }^{27}$ Moreover, in periods of drought, local governments have purchased water rights from power generators using tax revenue. A number of water concessions for electricity generation are falling due in the near future. Consideration should be given to auctioning water rights.

\section{Ensuring sustainable groundwater use}

The management of groundwater resources in Spain faces a number of particular challenges: since most groundwater is used in agriculture, abstractions occur in a highly decentralised fashion, making their monitoring particularly difficult. In contrast to surface water, groundwater extraction costs are generally fully born by the users, at least in agriculture, as farmers develop and pay for groundwater extraction themselves. However, individual abstraction decisions generate incentives to overexploit the common resource ("tragedy of the commons"). Moreover, the gains in productivity obtained in agriculture from groundwater use are particularly large, greatly outweighing extraction costs (Custodio et al., 2010), reinforcing such incentives. These incentives to overexploit resources will rise further if prices for surface water supplies are raised and the supply of water is expanded to costlier sources such as recycled or desalinated water. An appropriate governance structure for groundwater management is therefore crucial.

27. A specific tax on hydroelectric generation is applied for example in Switzerland to appropriate some of the rents associated to water use. 


\section{The legal tools to stop excessive abstractions are not sufficiently effective}

The 1985 Water Law declared all groundwater to be in the public domain, so that subsequently established extractions required a concession from the relevant RBA. This allows the RBAs, in principle, to prevent excessive extractions through quantity rationing. However, owners of wells established before 1985 were given the right either to retain the private property right indefinitely, in which case the extraction characteristics (such as volume or depth of the drilling) could not be modified, or to retain the property right for 50 years, after which the right would be converted into a public concession. In any case, they were required to register their wells with the authorities. Current legislation does not allow for the introduction of a pricing mechanism to internalise the common resource externality.

In order to prevent overexploitation, the water act encourages users to establish associations. Such associations can, for example, gain representation in the decision-making bodies of the RBAs. The RBAs also have broad powers to regulate groundwater use in aquifers that are declared overexploited. For example, in such cases RBAs have to draw up management plans and determine pumping regimes. Moreover, the users of such aquifers are required to create a users' association.

While progress has been made in improving control of excessive groundwater abstractions, this framework has not been sufficiently effective to prevent overexploitation. Many aquifers subject to intensive use have not been declared overexploited (Custodio et al., 2010). The declaration of overexploitation has been subject to political and social debate and the strong representation of established users may generate risks of regulatory capture of the RBAs (López-Gunn, 2010). The authorities have improved sustainable water use by purchasing water rights in some cases, but at considerable budgetary cost.

Monitoring of abstractions has been weak (López-Gunn, 2010). Registration of groundwater abstraction rights established before 1985 is incomplete, undermining the enforcement of measures to prevent overexploitation. Several programmes were launched to remedy the situation: much progress has been made in registering abstraction rights and cancelling those which are obsolete. But observers note that many private wells remain undeclared and that illegal groundwater abstractions are still frequent (Custodio et al., 2010; Molinero et al., 2008). ${ }^{28}$ Limited financial resources from the government hold back such efforts (Custodio et al., 2010) and this situation is being aggravated by budget cuts, calling for increasing revenues from charges and fines. Enforcement also seems to suffer from lack of transparency in sanctioning, generating perceptions of uncertainty among groundwater users, which may reduce deterrence. The monitoring of groundwater abstractions should be reinforced. To this end the RBAs should be endowed with the necessary financial and human resources. In Australia, for example, requirements for drillers to provide well construction data for all wells drilled have been considered a useful tool to improve monitoring (ARMCAN, 1996).

\section{Self regulation through user associations could be reinforced}

The associations of aquifer users do not appear to have internalised the common resource externality associated to decentralised groundwater extractions effectively. While hundreds of such associations ${ }^{29}$ exist, few are oriented towards the sustainable use of a common resource. Most limit their activities to the joint use of infrastructure. On the other hand, there are notable examples of successful resource managers among these associations, which have set up internal mechanisms of abstraction controls and fines, without

28. For example, authors of research on the upper Guadiana basin suggest that "probably a majority" of groundwater abstractions were illegal and overexploitation has entailed the drying-off of protected wetland areas (Llamas and Martínez-Santos, 2005).

29. These can be associations of private or public law. 
requiring the authorities' intervention. As a result of their monitoring and maintenance activities, all associations may well have information advantages concerning water use relative to the administrative authorities. The government collaborates with the National Association of Groundwater Users (AEUAS) to promote collective management, with positive results. A representative of the association participates in the National Water Council. Some observers have noted that a better cooperation between RBAs and such user associations could make it easier for the authorities to gain access to such information (López-Gunn, 2010; Llamas and Martínez-Santos, 2005). These observers have noted that a wider participatory approach with a wide range of users (including those who can represent leisure and environmental benefits), and steps to make users better informed about requirements of sustainable use together with a less confrontational regulatory style, would improve enforcement.

Incentives of associations to co-operate and enforce sustainable groundwater resource use internally could be strengthened by introducing a charge on groundwater abstractions to users in those associations where abstractions are persistently above a sustainable level. As a result, members of such associations would have an incentive to set up effective enforcement mechanisms within their associations and to reveal information concerning illegal and unregistered water abstractions so as to avoid the introduction of such a charge. Legislation should be introduced to allow the introduction of a charge for groundwater abstractions to cover both the cost of administering and enforcing the groundwater rights as well as to internalise the common-resource externality. To create incentives for user associations to manage groundwater resources sustainably, such a charge could be introduced for those aquifers which are persistently not managed in a sustainable fashion. 


\section{Bibliography}

Aldaya, M.M. et al. (2010), "Water Footprint and Virtual Water Trade in Spain", in Garrido, A. and M. Llamas (ed.) (2010).

Ariño Ortiz, G. and M. Sastre Beceiro (2010), "Water Sector Regulation and Liberalisation”, in Garrido, A. and M. Llamas (ed.) (2010).

ARMCAN (1996), "Allocation and Use of Groundwater. A National Framework for Improved Groundwater Management in Australia", Occasional Paper, No. 2, Agriculture and Resource Management Council of Australia and New Zealand, Canberra.

Arrojo Agudo, P. (2010), “The End of Large-Scale Water Projects”, in Garrido, A. and M. Llamas (ed.) (2010).

Barcelò, D. (2008), Aguas continentales. Gestión de recursos hídricos, tratamiento y calidad del agua, Consejo Superior de Investigaciones Científicas.

Benito, B., F. Bastida and J. García (2010), "Explaining Differences in Efficiency: An Application to Spanish Municipalities", Applied Economics, Vol. 42, No. 4, Routledge.

Calatrava, J. and A. Garrido (2010), "Measuring Irrigation Subsidies in Spain: An Application of the GSI Method for Quantifying Subsidies", Institute for Sustainable Development, Geneva.

CICCP (Colegio de Ingenieros de Caminos, Canales y Puertos) (2010), "Hacia una gestión más eficiente del agua en España", Cuadernos de ordenación profesional, No. 20, Colegio de Ingenieros de Caminos, Canales y Puertos, Madrid, February.

Custodio, E. et al. (2010), "Issues Related to Intensive Groundwater Use”, in Garrido, A. and M. Llamas (ed.) (2010).

Dalhuisen, J., H. de Groot and P. Nijkamp (1999), "The Economics of Water: A Survey of Issues", Serie Research Memoranda, No. 36, Economics Faculty, Amsterdam University.

Gallart, F. and P. Llorens (2004), "Observations on Land Cover Changes and Water Resources in the Headwaters of the Ebro Catchment, Iberian Peninsula", Physics and Chemistry of the Earth, Vol. 29, No. 11-12, Elsevier.

García Novo, F., J. Toja Santillana and C. Grandado-Lorencio (2010), "The State of Water Ecosystems", in Garrido, A. and M. Llamas (ed.) (2010).

Garrido, A. and J. Calatrava (2009), "Agricultural Water Pricing: EU and Mexico", background report to OECD (2010a).

Garrido, A. and J. Calatrava (2010), "Trends in Water Pricing and Markets", in Garrido, A. and M. Llamas (ed.) (2010). 
Garrido, A. and M. Llamas (ed.) (2010), Water Policy in Spain, CRC Press.

Iglesias, A., M. Moneo, L. Garrote and F. Flores (2010), Drought and Climate Risks, in Garrido, A. and M. Llamas (ed.) (2010).

Llamas, R. and P. Martínez-Santos (2005), "Baseline Condition Report, Upper Guadiana Basin”, NeWater Report, No. 3, New Approaches to Adaptive Water Management under Uncertainty, EU research project, www.newater.info/index.php.

López-Gunn, E. (2010), "Making Groundwater Institutionally Visible”, in Garrido, A. and M. Llamas (ed.) (2010).

Maestu, J. and C.M. Gómez (2010), "Water Uses in Transition", in Garrido, A. and M. Llamas (ed.) (2010).

MARM (Ministry of Environment and Rural and Maritime Affairs) (2008a), Perfil ambiental de España 2008, Ministerio de Medio Ambiente y Medio Rural y Marino, Madrid.

MARM (2008b), Informe calidad del agua de consumo humano en España, Ministerio de Medio Ambiente y Medio Rural y Marino, Madrid.

MARM (2009a), El medio ambiente y el medio rural y marino en España 2008, Ministerio de Medio Ambiente y Medio Rural y Marino, Madrid.

MARM (2009b), Plan nacional de adaptación al cambio climático. Segundo programa de trabajo, Ministerio de Medio Ambiente y Medio Rural y Marino, Madrid.

MARM (2009c), Anuario estadísticó 2009, Ministerio de Medio Ambiente y Medio Rural y Marino, Madrid.

MARM (2010), "Versión preliminar de la Estrategia nacional para la Modernización Sostenible de los Regadíos Horizonte 2015", Ministerio de Medio Ambiente y Medio Rural y Marino, Madrid.

Martínez-Cortina, L. (2010), "Physical and Hydrololgical Characteristics", in Garrido, A. and M. Llamas (ed.) (2010).

MMA (Ministry of Environment) (2000), Libro blanco del agua en España (White Paper on Water in Spain), Ministerio de Medio Ambiente, Madrid.

MMA (2007a), El agua en la economía española : situación y perspectivas (Water in the Spanish Economy: Situation and Prospects), Serie monografías, Ministerio de Medio Ambiente, Madrid.

MMA (2007b), Precios y costes de los servicios del agua en España. Informe integrado de recuperación de costes de los servicios de agua en España (Prices and Costs of Water Services in Spain), Serie monografías, Ministerio de Medio Ambiente, Madrid.

Molinero, J. et al. (2008), "Groundwater in Spain: Overview and Management Practices", Revista de la Real Academia de Ciencias Exactas, Fisicas y Naturales, Vol. 102, No. 1, Universidad Complutense, Madrid.

OECD (2004), OECD Environmental Performance Reviews: Spain 2004, OECD Publishing, Paris. 
OECD (2006a), Infrastructure to 2030 (Vol. 2): Mapping Policy for Electricity, Water and Transport, OECD Publishing, Paris.

OECD (2006b), Infrastructure to 2030: Telecom, Land Transport, Water and Electricity, OECD Publishing, Paris.

OECD (2008), OECD Economic Surveys: Australia 2008, OECD Publishing, Paris.

OECD (2009), Managing Water for All: An OECD Perspective on Pricing and Financing, OECD Publishing, Paris.

OECD (2010a), Sustainable Management of Water Resources in Agriculture, OECD Publishing, Paris.

OECD (2010b), OECD Review of Agricultural Policies: Israel 2010, OECD Publishing, Paris.

OECD (2010c), Pricing Water Resources and Water and Sanitation Services, OECD Publishing, Paris.

Olmstead, S.M. and R.N. Stavins (2008), “Comparing Price and Non-Price Approaches to Urban Water Conservation", NBER Working Papers, No. 14147, National Bureau of Economic Research, Cambridge, MA.

OSE (Observatorio sobre la sostenibilidad en España) (2009), Sostenibilidad en España 2009, Informes Anuales del OSE, Observatorio sobre la sostenibilidad en España, Ministerio de Medio Ambiente y Medio Rural y Marino, Madrid.

Quentin Grafton, R. et al. (2010), "Water Markets: Australia's Murray-Darling Basin and the US Southwest", NBER Working Papers, No. 15797, National Bureau of Economic Research, Cambridge, MA.

Salgot, M. and M. Folch (2008), "Reutilización de aguas residuales" (Reuse of Residual Water), in Barceló, D. (ed.), Aguas continentales. Gestión de recursos hídricos, tratamiento y calidad del agua, Informes CSIC, Consejo Superior de Investigaciones Científicas, Madrid.

Schmidt, G. and L. De Stefano (2010), "Major Processes Degrading Freshwater Resources and Ecosystems", in Garrido, A. and M. Llamas (ed.) (2010).

Terceño-Gómez, A., J.M. Brotons-Martínez and J.A. Trigueros-Pina (2009), "Evaluación de las necesidades hídricas en España" (Assessment of Water Needs in Spain), Ingeniería hidráulica en México, Vol. 24, No. 4, Instituto Mexicano de Tecnología del Agua.

Varela Ortega, C. and N. Hernández-Mora (2010), "Institutions and Institutional Reform in the Spanish Water Sector", in Garrido, A. and M. Llamas (ed.) (2010). 


\section{WORKING PAPERS}

The full series of Economics Department Working Papers can be consulted at www.oecd.org/eco/workingpapers/

839. Increasing public sector efficiency in Slovakia (January 2011) by Felix Hüfner

838. Raising education outcomes in Switzerland (January 2011) by Andrés Fuentes

837. The Price Responsiveness of Housing Supply in OECD Countries (January 2011) by Aida Caldera Sánchez and Åsa Johansson

836. Housing markets and structural policies in OECD countries (January 2011) by Dan Andrews, Aida Caldera Sánchez and Åsa Johansson

835. Raising potential growth after the crisis: A quantitative assessment of the potential gains from various structural reforms in the OECD area and beyond (January 2011) by Romain Bouis and Romain Duval

834. The GDP impact of reform: a simple simulation framework (January 2011) by Sebastian Barnes, Romain Bouis, Philippe Briard, Sean Dougherty and Mehmet Eris

833. Improving the flexibility of the Dutch housing market to enhance labour mobility (January 2011) by Jens Høj

832. Making the Dutch pension system less vulnerable to financial crises (January 2011) by Jens Høj

831. Real house prices in OECD countries: the role of demand shocks and structural policy factors

(December 2010) by Dan Andrews

830. International financial integration and the external positions of euro area countries (December 2010) by Philip R. Lane

829. Improving fiscal performance through fiscal councils (December 2010) by Robert Hagemann

828. Minimising risks from imbalances in European banking (December 2010) by Sebastian Barnes, Philip Lane and Artur Radziwill

827. Resolving and avoiding unsustainable imbalances (December 2010) by Sebastian Barnes 
826. Current account imbalances in the euro area: a comparative perspective (December 2010) by Sebastian Barnes, Jeremy Lawson and Artur Radziwill

825. Does fiscal decentralisation strengthen social capital? Cross-country evidence and the experiences of Brazil and Indonesia (December 2010) by Luiz de Mello

824. Fiscal decentralisation and public investment: The experience of Latin America (December 2010) by Luiz de Mello

823. Product market regulation and competition in China (December 2010) by Paul Conway, Richard Herd, Thomas Chalaux, Ping He and Jianxun Yu

822. Reforming China's monetary policy framework to meet domestic objectives (December 2010) by Paul Conway, Richard Herd and Thomas Chalaux

821. Regulatory reforms to unlock long-term growth in Turkey (December 2010) by Rauf Gönenç and Łukasz Rawdanowicz

820. After the crisis: mitigating risks of macroeconomic instability in Turkey (December 2010) by Łukasz Rawdanowicz

819. The 2008-09 crisis in Turkey: performance, policy responses and challenges for sustaining the recovery (December 2010) by Łukasz Rawdanowicz

818. Fiscal-consolidation strategies for Canadian governments (November 2010) by Yvan Guillemette

817. The land transport sector: policy and performance (November 2010) by Jan Persson and Daeho Song

816. A simple model of the relationship between productivity, saving and the current account (November 2010) by Jean-Marc Fournier, Isabell Koske

815. The impact of structural policies on saving, investment and current accounts (November 2010) by Clovis Kerdrain, Isabell Koske, Isabelle Wanner

814. Towards a less distortive and more efficient tax system in Portugal (November 2010) by Alvaro Pina

813. Are global imbalances sustainable? Shedding further light on the causes of current account reversals (November 2010) by Luiz de Mello, Pier Carlo Padoan, Linda Rousová

812. Turkey's improving integration with the global capital market: Impacts on risk premia and capital costs (November 2010) by Rauf Gönenç, Saygin Şahinöz, Özge Tuncel 